\title{
Peran Lembaga Keuangan Desa dalam Meningkatkan Kesejahteraan Masyarakat
}

\author{
Andi Mardiana ${ }^{1}$ dan Wining E. Pakaya \\ 'Email: andimardianabone@gmail.com \\ 2Email: winingpky@gmail.com
}

\begin{abstract}
The research looked at the role of Rural Financial Institutions in improving public welfare of Oleleh Village of Kabila Bone in Bone Bolango District. This institution is an extension of the local government of Bolango Bone, this is the program for the welfare of society with the help of venture capital, either as fishermen, farmers as well as a small merchant, the results of this study found that the role of the village financial institutions can contribute to improve the welfare of society. This can be measured by several indicators, those are the return of agricultural land controlled by the middlemen, the primary requirement before the establishment of "LKD?" sometimes difficult to be fulfilled, but after this institution was established and worked, it can increase the income and the living conditions of local society.
\end{abstract}

Keywords: Village financial institutions, communities, prosperity.

\begin{abstract}
Abstrak
Penelitian ini melihat peran Lembaga Keuagan Desa dalam meningkatkan kesejahteraan masyarakat Desa Oleleh Kecamatan Kabila Bone Kabupaten Bone Bolango. Lembaga ini merupakan perpanjangan tangan dari pemerintah daerah Kabupaten Bone Bolango, ini merupakan program untuk mensejahterakan masyarakat dengan bantuan modal usaha, baik sebagai nelayan, petani maupun sebagai pedagan kecil, dari hasil penelitian ini ditemukan bahwa peran lembaga keuangan Desa dapat menberikan konstribusi terhadap peningkatan kesejahteran masyakat. Hal ini dapat diukur melalui beberapa indikator antara lain kembalinya lahan pertanian yang dikuasai oleh para tengkulak, kebutuhan primer yang sebelum adanya LKD terkadang sulit terpenuhi, tapi setelah lembaga ini dibentuk dan berjalan maka pendapatan masyarakat dapat meningkat dan taraf hidup mereke bertambah baik.
\end{abstract}

Kata Kunci: Lembaga keuangan desa, masyarakat, kesejaheteraan. 


\section{A. Pendahuluan}

Islam adalah agama rahmatan lil 'alamin, sebuah sebutan yang menuntut keyakinan dan pengkajian mendalam terhadap nilai esensial dari pengenaan kata "rahamatan". Terlepas dari itu semua, Islam yang dalam kajian globalnya telah menempatkan pengaturan kehidupan umatnya dalam berbagai aspek pola kehidupan secara maksimal.

Dalam Islam, manusia diwajibkan untuk memanfaatkan sumber kekayaan alam yang tersedia dengan baik dengan mempertimbangkan kebutuhan sekarang dan kebutuhan masa yang akan datang. Sesungguhnya Allah swt. sang pencipta alam semesta menciptakan segala yang ada dibumi untuk manusia. Dan manusia diberi tanggung jawab, karena pada dasarnya manusia adalah khalifah dimuka bumi untuk mengelolah dan mempergunakan apa yang menjadi karunia. Sebagaimana yang ditegaskan oleh Allah swt dalam ayat Al-qur'an surat Al-Baqarah ayat : 109
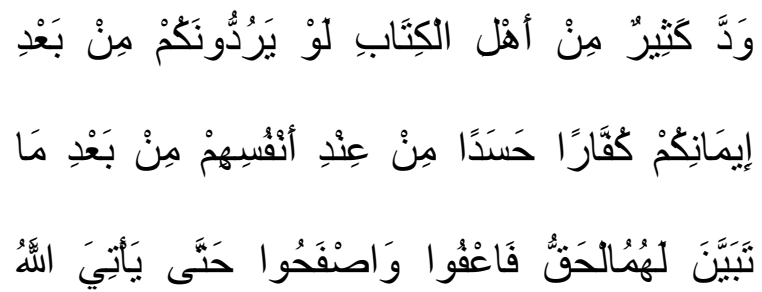

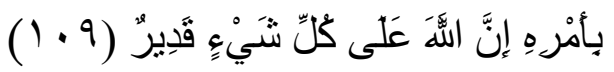

Terjemahan:

"Sebahagian besar ahli kitab menginginkan agar mereka dapat mengembalikan kamu kepada kekafiran setelah kamu beriman, karena dengki yang (timbul) dari diri mereka sendiri, setelah nyata bagi mereka kebenaran. Maka ma'afkanlah dan biarkanlah mereka, sampai Allah mendatangkan perintah-Nya." (Al Baqarah : 109 )
Banyak ayat Al-qur'an dan Hadits Nabi SAW. yang memerintahkan manusia agar mengelola karunia Allah SWT. dan tidak melanggar garis-garis yang telah ditentukan-Nya. Dengan demikian manusia dapat menyadari bahwa apa yang ada sekarang dikelola dengan baik. Baik kekayaan yang di darat maupun yang ada di laut agar ia mendapatkan rezeki guna memenuhi kebutuhan hidupnya. Islam juga mengajarkan kepada manusia bahwa Allah maha pemurah sehingga rezekinya sangat luas. Bahkan, Allah tidak memberikan rezeki itu kepada kaum muslimin saja, tetapi kepada siapa saja yang bekerja keras.

Wilayah Indonesia terbentang dari Sabang sampai Merauke. Lautan dan daratan yang luas kaya dengan berbagai potensi, dimanfaatkan oleh masyarakat sebagai sumber penghidupan. Kekayaan Nusantara merupakan potensi sumber penghidupan yang tidak akan pernah habis.

Pembangunan ekonomi kerakyatan merupakan hal yang sangat sensitif. Pemerintah dalam pemberdayaan hasilhasil alam tentunya membutuhkan masyarakat sebagai subjeknya. Hal ini dimaksudkan agar sistem ekonomi yang merugikan masyarakat dapat dihindari. Sebagaimana yang dinyatakan oleh Muhammad Sofyan bahwa Islam memandang pemahaman materi adalah segalanya bagi kehidupan sebagaimana menurut kaum kapitalisme adalah merupakan pemahaman yang salah, sebab manusia selain memiliki dimensi material juga memiliki dimensi non material (spiritual). Dalam realitanya tampak sekali bahwa paham materialisme membawa kehidupan manusia kepada kekayaan, kesenangan dan kenikmatan fisik belaka dengan mengabaikan dimensi non materi (http://www.msi-uii.net) 
Kesejahteraan sosial akan tercipta dalam sistem masyarakat yang stabil, khususnya stabilitas keamanan, dan stabilitas sosial. Ekonomi tidak mungkin terjamin tanpa adanya stabilitas keamanan (termasuk di dalamnya stabilitas politik). Sebuah negara yang stabilitas keamanannya rawan akan berpengaruh terhadap berbagai sektor kehidupan lainnya. Kinerja sektor ekonomi yang merupakan faktor penyangga kesejahteraan akan terganggu bahkan terbengkalai sama sekali. Begitu pula stabilitas politik, fakta menunjukkan bahwa negara-negara dunia ketiga yang terus dilanda kemelut krisis dalam Negeri seperti membengkaknya hutang, angka pengangguran, dan berseminya kawasan kumuh dan miskin (kumis) disebabkan karena stabilitas keamanan dan politik yang labil.

Pembangunan ekonomi dalam prespektif Islam adalah pembangunan yang menguntungkan semua pihak, bukan pembangunan yang mengangkat kesejahteraan sekelompok individu dan menurunkan kesejahteraan yang lain. Islam mengerakkan perilaku ekonomi yang dilandasi prinsip ta'awun (tolong menolong) dan memperoleh hasil atau keuntungan yang tidak merugikan salah satu pihak (Husain, 2004: xxiv). Oleh karena itu, Islam secara tegas mengharamkan sistem riba yang nyata merusak semangat berkhidmat kepada masyarakat

Konsep Islam mengenai muamalah sangat baik, karena menguntungkan semua pihak yang terlibat di dalamnya. Namun bisa merugikan pihak lain apabila moral manusia pelakunya tidak baik. Hal inilah yang menyebabkan akad (transaksi) dipergunakan sebagai alat untuk memeras, menipu dan merugikan orang lain. Keadilan dan pemerataan pendapatan adalah salah satu komponen yang terpenting dalam pandangan Islam terhadap tatanan sosial ekonomi yang adil (Ahmad, 1998; 2). Segi yang paling patut diperhatikan dalam skema pemerataan pendapatan adalah adanya jaminan pemenuhan kebutuhan dasar bagi seluruh rakyat, serta tidak terlepas dari campur tangan pemerintah.

Desa Olele adalah sebuah desa yang terpencil, terdapat di Kecamatan Kabila Bone Kabupaten Bone Bolango merupakan salah satu desa yang mempunyai potensi di segala sektor usaha. Jika dipersentasekan bidang usaha dimaksud, maka terlihat bahwa nelayan $69 \%$, petani 31\%, dagang kecil 2\%. Meskipun ada perbedaan dalam jumlah, akan tetapi semua telah diupayakan untuk bisa dijamah oleh program pemerintah. Diantara banyak program, salah satunya yang cukup menarik untuk dibahas adalah program Masyarakat Mandiri Pangan (MAPAN).

Program Masyarakat Mandiri Pangan (MAPAN) merupakan program unggulan berasal dari Departemen Pertanian, Perkebunan, Ketahanan Pangan, dan Peternakan, yang dalam hal ini dibagi atas dua bagian yaitu tim pangan (TPD) dan Lembaga Keuangan Desa (LKD). Kedua tim ini bergerak dibidang ekonomi dengan tujuan untuk mensejahterakan masyarakat secara keseluruhan. Khususnya di Desa Olele program ini telah dijalankan sejak lama.

Informasi yang diterima sesuai penyampaian ketua Lembaga Keuangan Desa (LKD) bahwa, lembaga ini telah Berdiri sejak tahun 2008. Lembaga ini merupakan perpanjangan tangan dari pemerintah daerah Kabupaten Bone Bolango, berupaya keras untuk mensejahterakan masyarakat. Biasanya masalah berkembang dan kemajuan hidup khususnya di Desa Olele diakibatkan oleh rendahnya pendapatan masyarakat yang menyebabkan ketidak mampuan membuka 
usaha, tidak punya tabungan, sulit mengembangkan usaha bidang pertanian, nelayan, dan biaya pendidikan tidak ada sehingga kwalitas sumber daya manusia sangat rendah (Michtar Amu, Ketua LKD, Desa Olele 2013).

Oleh karena rendahnya pendapatan masyarakat, maka tingkat kesejahteraan juga sangat rendah. Sebab itulah pemerintah dengan program masyarakat mandiri pangan (MAPAN), lewat Lembaga keuangan desa (LKD), mencoba membangun perekonomian, meningkatkan kesejahteraan masyarakat dengan sistim pembiayaan, dengan mengoptimalkan sumber daya alam serta sumber daya manusia untuk meningkatkan kesejahteraan masyarakat yang terlibat di dalamnya.

Adapun dana awal yang dikucurkan oleh pemerintah lewat Lembaga Keuangan Desa (LKD) sebesar 100 juta rupiah. Dana tersebut diperuntukan bagi masyarakat yang tingkat ekonominya lemah dan memiliki keinginan untuk berusaha. Sturktur masyarakat yang banyak merasakan manfaat bantuan tersebut yaitu nelayan, petani, pedagang kecil, dan peternakan. Dengan sistim pembiayaan. Meskipun demikian, dua hal yang ditawarkan oleh LKD dalam penerapan sistim pembiayaan terhadap masyarakat yaitu pengadaan barang, dan penambahan modal (Tiyong Mahmud, Bendahara LKD , Desa Olele Kec. Kabila Bone 2013). Dengan harapan pilihan ini tidak akan menyusahkan masyarakat tetapi terbantu dan maju dalam meningkatkan usaha yang mereka tekuni.

\section{B. Landasan Konseptual}

Lembaga Keuangan adalah badan usaha yang kekayaannya terutama dalam bentuk aset keuangan atau tagihan (claims) dibandingkan aset nonfinancial atau aset riil. Lembaga keuangan memberikan kredit kepada nasabah dan menanamkan dananya dalam surat-surat berharga. Di samping itu, lembaga keuangan juga menawarkan berbagai jasa keuangan antara lain menawarkan berbagai jenis skema tabungan, proteksi asuransi, program pension, penyediaan sistem pembayaran dan mekanisme transfer dana. Lembaga keuangan merupakan bagian dari sistem keuangan dalam ekonomi modern yang melayani masyarakat pemakai jasa-jasa keuangan.

Lembaga keuangan dalam dunia keuangan bertindak selaku lembaga yang menyediakan jasa keuangan bagi nasabahnya, dimana pada umumnya lembaga ini diatur oleh regulasi keuangan dari pemerintah. Bentuk umum dari lembaga keuangan ini adalah termasuk perbankan, building society (sejenis koperasi di Inggris), Credit Union, pialang saham, aset manajemen, modal ventura, koperasi, asuransi, dana pensiun, dan bisnis serupa lainnya.

Lembaga keuangan (lembaga intermediasi) dapat dikelompokkan dalam berbagai cara. Pengelompokkan yang paling umum dan mudah dimengerti adalah mengelompokkan lembaga keuangan berdasarkan kemampuannya menghimpun dana dari masyarakat secara langsung. Atas dasar tersebut lembaga keuangan dapat dibedakan menjadi lembaga keuangan depositori (depository financial institution) dan lembaga keuangan non-depositori (non depository financial institution).

Lembaga keuangan depositori. Lembaga keuangan ini menghimpun dana secara langsung dari masyarakat dalam bentuk simpanan misalnya giro, tabungan atau deposito berjangka yang diterima dari penabung atau unit surplus. Unit surplus dapat berupa perusahaan, pemerintah dan rumah 
tangga yang memiliki kelebihan pendapatan setelah dikurangi kebutuhan untuk konsumsi. Lembaga keuangan yang menawarkan jasa-jasa seperti ini adalah bank-bank.

Lembaga keuangan non depositori, Lembaga keuangan bukan bank. Lembaga yang masuk dalam kelompok ini adalah lembaga keuangan yang kegiatan usahanya bersifat kontraktual yaitu menarik dana dari masyarakat dengan menawarkan kontrak untuk memproteksi penabung terhadap risiko ketidakpastian misalnya polis asuransi, program pensiun. Kelompok lembaga keuangan ini dapat disebut perusahaan asuransi dan dana pensiun. Lembaga keuangan investasi yaitu lembaga keuangan yang kegiatannya melakukan investasi di pasar uang dan pasar modal, misalnya perusahaan efek, resadana. Lembaga keuangan bukan bank lainnya yang kegiatan usahanya tidak termasuk dalam kelompok lembaga keuangan kontraktual dan investasi yaitu perusahaan modal ventura dan perusahaan pembiayaan yang menawarkan jasa pembiayaan sewa guna, anjak piutang, pembiayaan konsumen dan kartu kredit.

Lembaga keuangan ini menyediakan jasa sebagai perantara antara pemilik modal dan pasar utang yang bertanggung jawab dalam penyaluran dana dari investor kepada perusahaan yang membutuhkan dana tersebut. Kehadiran lembaga keuangan inilah yang memfasilitasi arus peredaran uang dalam perekonomian, dimana uang dari individu investor dikumpulkan dalam bentuk tabungan sehingga risiko dari para investor ini beralih pada lembaga keuangan yang kemudian menyalurkan dana tersebut dalam bentuk pinjaman utang kepada yang membutuhkan. Ini adalah merupakan tujuan utama dari lembaga penyimpan dana untuk menghasilkan pendapatan. Contoh dari lembaga keuangan adalah bank (http://ayutyap.blogspot.com/2011/1l/defini si-lembaga-keuangan).

Hal senada dengan program masyarakat mandiri pangan (MAPAN), lembaga keuangan desa (LKD) adalah merupakan persekutuan yang berbentuk badan hukum, memiliki karyawan yang dapat bekerja sama untuk mencapai hasil yang lebih baik dengan lebih cepat/melaksanakan proses lebih baik ditempat kerja.

Adapun fungsi LKD sebagai berikut

1. Mengelola dana PUMK yang berasal dari APBN yang disalurkan kepada masyarakat dengan sasaran untuk kegiatan usaha ekonomi produktif

2. Menerima pengembangan dana PUMK dari kelompok afinitas

3. Menyalurkan kembali dana penguatan modal kepada kelompok yang sama atau kelompok baru atas rekomondasi TPD dan pendamping

4. Ketua LKD memberikan laporan perkembangan keuangan kepada dinas/kantor/unit ketahanan pangan setiap satu semester (6 bulan sekali) (Ishak Ntoma, Dinas Pertanian).

Dari tugas dan fungsi LKD di atas terlihat jelas bahwa lembaga ini bergerak disegala bidang usaha secara luas untuk percepatan pembangunan ekonomi kerakyatan yang memiliki daya tarik, daya tahan, dan daya saing untuk segera menuju masyarakat sejahtera, berkeadilan dan mandiri dengan mengembangkan dan memanfaatkan jaringan kerja sama antara Lembaga dan masyarakat.

Lembaga keuangan desa meluncurkan segala program dengan visi dan misi yang jelas sebagai acuan dalam menjalankan program yang telah ditetapkan untuk kemudian menjadi acuan dan target capain dalam menjalankan usaha 
kepada masyarakat sekaligus demi masyarakat pula.

Visi dan misi Lembaga Keuangan Desa terulas sebagai berikut:

a. Visi

Membangun mengoptimalkan potensi sumber daya manusia untuk meningkatkan kesejahteraan masyarakat yang terlibat didalamnya.

b. Misi

(1) Memberdayakan sumber daya manusia yang tersedia di daerah menjadi tenaga-tenaga yang terampil dan mencintai pertanian.

(2) Mengali kemauan masyarakat lebih berkeinginan untuk memajukan usaha yang telah ditekuni sejak lama (Tiyong Mahmud Bendahara LKD Wawancara tanggal 12 Okt 2013) Jelasnya visi dan misi LKD memunculkan tiga macam program yang diistilahkan dengan produk kemitraan di bawah ini:

a. Program Pembiayaan Lahan

Lembaga Keuangan Desa (LKD) memberikan biaya yang menjadi modal untuk masyarakat dalam mengelola lahan yang telah dibuka dalam bentuk pinjaman modal. Kemudian pengembalian modal disetor setiap bulan kepada bendahara lembaga keuangan desa. Namun dalam hal penyetorannya sesuai kesepakatan dan perjanjian yang telah ditanda tangani oleh para pengguna dana pada surat pernyataan. Aturan yang telah diberlakukan oleh Lembaga Keuangan Desa bahwa, setiap peminjam harus ada barang sebagai jaminan. Akan tetapi dalam hal jaminan tersebut hanyalah sebagai peguatan dan sekaligus penjagaan jangan sampai dalam penyetorannya masyarakat akan ada yang melanggar ketentuan yang telah disepakati. b. Program Sarana Produksi Pertanian
Lembaga keuangan desa menyediakan sarana produksi pertanian untuk memudahkan petani dalam mengelola tanaman seperti pupuk dan bibit. Pupuk tersebut akan dijual kepada petani dengan harga murah, yang pembayarannya dapat dilakukan setelah panen. Selain itu meskipun ketentuan itu ada, akan tetapi jika masyarakat gagal panen, maka pembayaran pupuk dan bibit yang diadakan oleh Lembaga Keuangan Desa bisa saja belum dibayar, dengan alasan dan bukti yang kuat sesuai pengamatan tim yang ditugaskan oleh lembaga untuk mengamati secara langsung kejadian gagal panen yang disampaikan oleh masyarakat pemanfaat pupuk dan bibit.

Hal ini dilakukan oleh lembaga dengan alasan setelah ada aturan masih ada kebijakan yang menjadi cela untuk memberikan kemudahan kepada masyarakat dalam hal pembayaran, tanpa harus memberikan penjelasan kebijakan yang ril, agar nantinya masyarakat tetap terikat dengan utang yang harus dibayar dengan disiplin sesuai ketetapan.

c. Program Sarana Alat Mesin Nelayan

Lembaga Keuangan Desa (LKD) juga mengadakan mesin katingting kepada masyarakat nelayan dengan cara memberikan pinjaman modal melebihi harga barang dan sisanya tidak untuk dikembalikan, dan untuk pengadaannya, masyarakat sendiri yang akan membeli dari toko terdekat, dan tidak lepas dari kontrol lembaga yang mengadakan modal. Bentuk pengembalian modal masyarakat peminjam menyetor kepada lembaga keuangan desa pada setiap bulannya.

Dari progaram sarana produksi pertanian dan program sarana alat mesin nelayan terlihat adanya perbedaan. Masyarakat nelayan dituntut harus membayar setiap bulan sementara para petani membayar jika berhasil panen. 
Perbedaan ini tidak harus menjadi perbandingan antara masyarakat, sebab alasan yang cukup mendasar terhadap lembaga melakukan itu, dikarenakan melihat resiko yang dihadapi nelayan sangat kecil (Lutfi Rahman, Sekertaris LKD Desa Olele 2013).

Tiga program di atas, yang dijalankan oleh Lembaga keuangan Desa, di desa Olele kec. Kabila Bone pada intinya mencakup dua hal pokok yaitu, harapan kesejahteraan sosial yang bersifat jasmani (lahir) dan rohani (batin). Seperti halnya kesejahteraan dalam islam, sejahtera lahir dan batin tersebut harus terwujud dalam setiap pribadi (individu) yang bekerja untuk kesejahteraan hidupnya sendiri, sehingga akan terbentuk keluarga/masyarakat dan negeri yang sejahtera.

\section{Metode Penelitian}

Untuk pengumpulan data dan informasi melalui wawancara mendalam dan diskusi dengan pimpinan, karyawan Lembaga Keuangan Desa (LKD), nelayan, petani lahan Kering (kebun) dan semua unsur yang dapat memberikan data informasi dan penelitan ini menggunakan jenis penelitian kualitatif deskriptif dengan mengunakan pendekatan Sosial dan
Ekonomi Islam. Penjelasan dan pemaparan dilakukan dengan kata-kata atau kalimat yang dipisah-pisahkan menurut kategori untuk memperoleh kesimpulan, mengingat kehadiran peneliti sebagai subjek peneliti sangat berpengaruh pada penelitian itu sendiri, maka peneliti hadir pada pelaksanaan penelitian sebagai instrumen utama dan pengumpul data, dan berperan penuh dalam penelitian ini.

\section{Temuan Penelitian}

Desa olele adalah salah satu Desa pemekaran dari desa Oluhuta yang terletak di Kabupaten Bone Bolango. Desa ini terletak sebelah Timur Kecamatan Kabila Bone, jumlah penduduk Desa Olele adalah 1.031 jiwa, terdiri dari penduduk laki-laki 541 jiwa dan penduduk perempuan 490 jiwa. Kepadatan penduduk Desa Olele sebesar 1.031 jiwa per km2. Dusun yang paling padat penduduknya adalah Dusun Hungayo Kiki 228 jiwa/ km2, sedangkan yang terendah penduduknya adalah Dusun Olele Tengah 218 jiwa /per km2.

Rasio jenis kelamin penduduk Desa Olele Ini berarti bahwa untuk setiap 100 penduduk perempuan terdapat 112 penduduk laki-laki, atau dapat dikatakan jumlah penduduk Laki-laki di Desa Olele lebih banyak dari penduduk Perempuan.

Tabel 1 Jumlah Penduduk, Jenis Kelamin dan Sex Rasio Diperinci Per Dusun

\begin{tabular}{|c|l|c|c|c|}
\hline \multirow{2}{*}{ NO } & \multirow{2}{*}{ DUSUN } & \multicolumn{2}{|c|}{ Jumlah Penduduk } & \multirow{2}{*}{$\begin{array}{c}\text { Rasio jenis } \\
\text { kelamin }\end{array}$} \\
\cline { 3 - 4 } & & Laki-Laki & Perempuan & 357 \\
\hline 1 & IDANTO & 200 & 157 & 218 \\
\hline 2 & OLELE TENGAH & 108 & 110 & 228 \\
\hline 3 & PENTADU & 113 & 115 & 228 \\
\hline 4 & HUNGAYO KIKI & 120 & 108 & 1.031 \\
\hline \multicolumn{2}{|l|}{ JUMLAH } & 541 & 490 & \\
\hline
\end{tabular}

Sumber d ata : Kecamata Kabila Bone Dalam Angka, 2014

Kepadatan penduduk Desa Olele merata hal ini dapat dilihat pada tabel di atas. Penduduk terbanyak terletak pada
Dusun Idanto, hal ini disebabkan kawasan dusun tersebut lebih luas di banding dusun yang lain. 
Tabel 2 Jumlah Penduduk Yang Bekerja Menurut Lapangan Usaha diperinci Per Dusun Desa Olele Kec Kabila Bone 2009

\begin{tabular}{|c|c|c|c|c|}
\hline DUSUN & Pedagang & $\begin{array}{c}\text { Pegawai } \\
\text { Negeri }\end{array}$ & Nelayan & Pertanian \\
\hline IDANTO & 7 & 2 & 10 & 49 \\
\hline $\begin{array}{c}\text { OLELE } \\
\text { TENGAH }\end{array}$ & 8 & 6 & 30 & 6 \\
\hline PENTADU & 9 & 2 & 45 & 3 \\
\hline $\begin{array}{c}\text { HUNGAYO } \\
\text { KIKI }\end{array}$ & 6 & - & 64 & 1 \\
\hline
\end{tabular}

Sumber data : Kecamatan Kabila Bone Dalam Angka, 2014

Penduduk Desa Olele terperinci menurut lapangan usaha seperti terlihat pada tabel di atas berjumlah 248 Kepala keluarga, sementara sesuai informasi dari salah seorang staf pemerintahan Desa Olele ( Sirko Rahman) bahwa keseluruhan Kepala Keluarga berjumlah 296 KK, ini terbukti masih ada beberapa kepala keluarga yang belum memiliki usaha yang menetap, dan masyarakat seperti ini yang belum bisa ditangani oleh lembaga keuangan desa.

Kepala keluarga yang tercatat pada tabel di atas terlihat, dalam bidang usaha dagang berjumlah 30 kepala keluarga, yang berkedudukan sebagai pegawai negeri sipil berjumlah 10 kepala keluarga, yang bekerja sebagai nelayan berjumlah 149 kepala keluarga, sementara yang bekerja dibidang pertanian berjumlah 59 kepala keluarga. Dari data ini yang mendapat perhatian khusus dari lembaga keuangan desa adalah petani dan nelayan.

Dalam bidang pertanian dengan jumlah 59 kepala keluarga yang telah terjangkau oleh lembaga keuangan desa berjumlah 56 kepala keluarga dan yang belum terjangkau berjumlah 3 kepala keluarga, begitu juga usaha nelayan, sesuai data berjumlah 149 kepala keluarga dan yang telah terjangkau oleh lembaga keuangan desa berjumlah 94 kepala keluarga, dan yang belum terjangkau berjumlah 55 kepala keluarga. 
Struktur Organisasi Lembaga Keuangan Desa (LKD) di Desa Olele

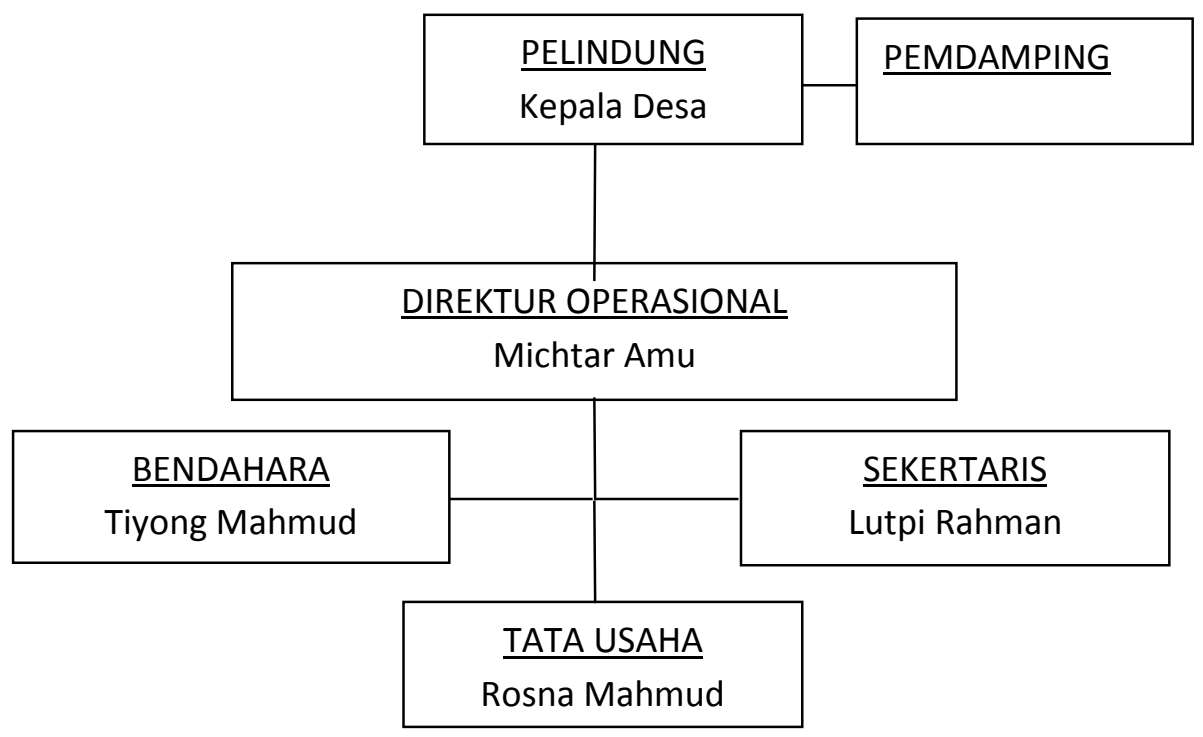

1. Keadaan Sarana dan Prasarana Informasi ini diperoleh dari Lembaga Lembaga Keuangan Desa (LKD) Desa Keuangan Desa melalui wawancara dengan Olele

Setelah terbentuk tahun 2008 Desa, Bapak Michtar Amu. Hasil Lembaga Keuangan Desa (LKD) telah wawancara tersebut dilihat pada tabel mempunyai beberapa sarana dan Prasarana berikut ini : yang sampai saat ini dipergunakan. Tabel 3 Keadaan sarana dan Prasarana Lembaga Keuangan Desa (LKD) Tahun 2010

\begin{tabular}{|l|l|c|c|c|}
\hline \multirow{2}{*}{ No } & \multicolumn{2}{|c|}{ Uraian } & \multirow{2}{*}{ Jumlah } & \multicolumn{2}{|c|}{ Keadaan } \\
\cline { 4 - 6 } & & & Baik & Buruk \\
\hline l. & Gedung & 1 & $\checkmark$ & - \\
\hline 2. & Komputer & 1 & $\checkmark$ & - \\
\hline 3. & Kursi Karyawan & 4 & $\checkmark$ & - \\
\hline 4. & Lemari & 1 & $\checkmark$ & - \\
\hline 5. & Meja & 4 & $\checkmark$ & - \\
\hline 6. & Printer & 1 & $\checkmark$ & \\
\hline
\end{tabular}

Sumber : Wawancara dengan Ketua LDK

2. Jumlah Karyawan pada Lembaga Keuangan Desa (LKD) Desa Olele

Jumlah karyawan tetap Lembaga Keuangan Desa saat ini berjumlah 4 orang, yang pada dasarnya mereka bergerak dalam tugas sesuai tugas pokok masing-masing yang tidak pernah lepas dari kontrol visi dan misi yang telah ditetapkan oleh lembaga

3. Aktivitas Awal Lembaga Keuangan Desa (LKD)

Dalam perkembangannya aktivitas usaha awal Lembaga Keuangan Desa secara 
umum yaitu aktivitas usaha yang bersifat profit oriented.

Program Lembaga Keuangan Desa (KLD) Olele dimaksudkan untuk membantu masyarakat petani dan nelayan dalam memaksimalkan lahan dan alat nelayan, melalui pemberian bantuan bibit, alat pertanian, alat mesin nelayan, dan dalam bentuk pinjaman dana tunai yang akan dikembalikan dalam jangka waktu tertentu oleh para peminjam. Program ini hampir sama kerjanya dengan Koperasi atau Bank, bedanya LKD dikelola menurut sistem yang diatur bersama-sama dengan masyarakat, guna meningkatkan kesejahteraan meningkatkan kesejahteraan petani dan nelayan.

Berdasarkan hasil penelitian yang telah dilaksanakan pada kelompok petani dan nelayan sampel, diperoleh jawaban yang dominan tentang peran LKD dalam meningkatkan kesejahteraan masyarakat. Sesuai hasil pengkajian tentang indikator kesejahteraan masyarakat, ditetapkan sebanyak 3 aspek, yakni: kebutuhan primer, kebutuhan sekunder dan tersier.

1.

Peranan

Program Kemitraan Lahan Lembaga Keuangan Desa (LKD) Desa Olele dalam Meningkatkan kesejahteraan Petani di Desa Olele

Lembaga Keuangan Desa adalah salah satu program Pemerintah Kabupaten Bone Bolango yang tujuannya meningkatkan kesejahteraan petani, baik petani sawah dan petani lahan kering. Namun dalam hal ini, mengingat petani sawah di Desa Olele tidak ada, maka alokasi dana keseluruhan dari sebagian yang telah dianggarkan diarahkan sepenuhnya kepada petani lahan kering. Program ini dibuat dalam rangka menanggulangi angka kemiskinan di
Kabupaten Bone Bolango khususnya Desa Olele Kecamatan Kabila Bone. Bapak Repin Launuha (Idanto, wawancara, tanggal 3 juli 2014) salah seorang masyarakat yang juga menekuni pekerjaan sebagai petani lahan kering yang diperkirakan lahan yang dimiliki seluas $1 \mathrm{Ha}$ lebih mengatakan bahwa Lembaga Keuangan Desa telah membantu masyarakat dalam meningkatkan kesejahterakan khususnya masyarakat petani melalui program kemitraan lahan.

Peranan Program kemitraan lahan Lembaga Keuangan Desa meliputi :

a. Pemberian modal untuk menunjang masyarakat petani dalam bekerja selama hasil belum terlihat

b. Pemberian pupuk sesuai kebutuhan oleh LKD terhadap masyarakat petani, yang hal ini dihitung dari harga pupuk selanjutnya dicatat sebagai utang pinjaman yang nantinya akan dikembalikan kepada LKD sesuai ketentuan waktu dan bunga yang disetujui.

Masalah ada pemaksaan dan ketentuan harga yang harus dibayarkan setiap kali panen. Sistem bagi hasil yang digunakan oleh Lembaga Keuangan Desa yaitu $1 / 3$ dan 2/3 dalam hal ini Lembaga Keuangan Desa sebagai pemberi modal, sementara mendapatkan $1 / 3$ bagian dari hasil panen, sedangkan petani mendapatkan $2 / 3$ bagian, yang $2 / 3$ bagian ini kemudian dibagi lagi menjadi $1 / 3$ untuk pembayaran hutang ke Lembaga Keuangan Desa dan 1/3 lagi untuk petani sebagi pemilik lahan. Dari proses pembagian tersebut, petani telah terbantu karena lahan mereka dapat kembali kepada mereka sepenuhnya tanpa mengembalikan uang tunai kepada Lembaga Keuangan Desa.

Hal senada di ungkapkan oleh bapak Loyan Arsyad (wawancara,tanggal 5 
juli 2014), program penambahan modal oleh Lembaga Keuangan Desa kepada masyarakat nelayan merupakan salah satu jalan keluar dari hutang yang membelitnya. Sebelum bekerja sama dengan Lembaga Keuangan Desa beliau merasa sangat kekurangan dalam memenuhi kebutuhan hidupnya sehari-hari. Hal ini karena melaut sebagai objek untuk mencari nafkah, sedangkan peralatan nelayannya masih sangat manual sehingga sangat sulit untuk bisa bersaing dengan orang-orang yang sudah menggunakan mesin untuk bisa menempuh rakit yang jauhnya beberapa $\mathrm{km}$ dari bibir pantai. Setelah beliau dimodali oleh Lembaga Keuangan Desa, ia sudah dapat membayar hutang dengan hasil yang di peroleh dari melaut.

Bapak Usman Hamdata (Wawancara, tanggal 7 juli 2014) salah seorang pedagang kecil yang berasal dari dusun Olele Tengah menyatakan bahwa pemberian tambahan modal dapat meningkatkan kesejahteraan para pedagang kecil. Alasanya dengan program pemberian tambahan modal ini pedagang kecil bisa meningkatkan lagi barang-barang dagangan yang sangat dibutuhkan oleh masyarakat, hanya saja karena modalnya hanya sedikit sehingga barang-barang yang di dagangkan juga sangat terbatas maka keuntungannya juga sangat minim, kemudian setelah modal ditambahkan oleh Lembaga Keuangan Desa maka penghasilan yang didapatkannya sudah lebih maksimal di banding sebelum meminjam, bahkan dengan hasil dari dagang itu beliau sudah bisa membeli sepeda motor meskipun hanya dengan cara menicil.

Dari penjelasan ketiga informan diatas penulis menyimpulkan bahwa Lembaga Keuangan Desa mempunyai andil yang sangat besar dalam meningkatkan kesejahteraan masyarakat kecil. Secara umum kesejahteraan masyarakat diartikan sebagai kondisi sejahtera dimana terpenuhinya segala bentuk kehidupan manusia, khususnya yang bersifat mendasar seperti makanan, pakaian, perumahan, pendidikan dan perawatan kesehatan. Dari pengertian kesejahteraan diatas melalui program penambahan modal, Lembaga Keuangan Desa mampu meningkatkan kesejahteraan masyarakat khususnya petani karena setelah di berikan modal oleh Lembaga Keuangan Desa, lahan tersebut seolah bukan milik orang lain lagi, akan tetapi menjadi milik mereka dan dapat dikelola sendiri oleh pemilik lahan sehingga dari hasil pengelolaan lahan tersebut kebutuhan makanan, pakaian, pendidikan dan kesehatan dapat terpenuhi.

Lembaga Keuangan Desa Di Desa Olele dalam menjalankan programnya selalu mementingkan nasib para peminjam. Perbedaan mendasar antara Lembaga Keuangan Desa dengan lembaga lain seperti KUD, PNPM Mandiri adalah dalam hal pengambilan keputusan. Lembaga Keuangan Desa selalu mementingkan siapa yang membutuhkan, bukan siapa yang sudah lengkap berkasnya.

Pemberian Modal Lahan yang dilakukan oleh Lembaga Keuangan Desa sangat membantu petani. Dengan proses ini maka pemilik lahan yang sejak lama menggarap lahan tanpa merasa memiliki lagi, karena lahan mereka telah berhutang lebih awal kepada para tengkulak, kini telah merasa, kembali memiliki sepenuhnya akan lahan mereka sendiri . Hutang yang telah dibayar dari tengkulak untuk beberapa waktu masih di kuasai oleh Lembaga Keuangan Desa.

Perbedaanya jika dahulu mereka berhutang kepada tengkulak dengan konsekuensi hasil penen sepenuhnya jadi milik tengkulak dan mereka tidak bisa mengambil manfaat dari lahan tersebut tetapi setelah mereka bekerja sama dengan 
Lembaga Keuangan Desa melalui program pemberian modal lahan, lahan tersebut sudah kembali menjadi milik petani setelah cicilan penebusannya lunas.

Lembaga Keuangan Desa memberikan kemudahan kepada para pemilik lahan untuk melakukan cicilan tersebut sebagai berikut :

a. Para petani bisa membayar hutang kapan saja tanpa batas waktu tertentu.

b. Jika petani memiliki penghasilan lain pemilik lahan bisa melakukan pembayaran kepada Lembaga Keuangan Desa dengan penghasilan tersebut tanpa harus menunggu cicilan pada masa panen.

Hal tersebut tentunya membantu masyarakat dalam meningkatkan pendapatan petani. Karena sebelumnya petani pemilik lahan kemudian setelah berhutang pada tengkulak petani yang tadinya pemilik tanah beralih status menjadi penggarap, bahkan menjadi buruh tani. Sistem yang dilakukan oleh program pemberian modal lahan jika ditinjau dari Ekonomi Islam, mekanisme pengelolaan dan bagi hasil sudah sesuai dengan syariat Islam.

\section{Peran di bidang Sarana Produksi Pertanian}

Keadaan petani sebelum adanya lembaga keuangan desa dalam mengelola lahan pertanian sesungguhnya masih tergantung pada kesuburan tanah yang digarap. Sehingga jika lahan yang digarap dirasakan tidak subur lagi maka lahan itupun ditinggalkan dan pindah ke tempat lain mencari lahan yang menurut mereka masih bisa menunjang untuk kelangsungan hidup. Para petani Olele sebelum adanya LKD, gaya hidupnya seperti petani gurun di jajirah Arab yang suka berpindahpindah tempat.
Sebenarnya penanggulangan lahan yang telah dilakukan penanaman berulang telah ada sejak lama, yaitu pengadaan pupuk dari orang-orang tertentu yang bisa mengadaannya dengan sistim bisnis. Namun karena untuk mendapatkan pupuk harus membutuhkan modal yang cukup besar, kadang-kadang para petani juga tidak bisa memenuhi keperluan itu.

Program kemitraan lahan Lembaga Keuangan Desa juga menyiapkan Sarana Produksi Pertanian untuk memudahkan petani dalam proses bercocok tanam. Sarana Produksi Pertanian yang disediakan oleh Lembaga Keuangan Desa antara lain penyediaan pupuk urea dan ponska.Hal ini dilakukan agar petani tidak melakukan pembelian kepada pedagang pupuk dengan cara barter.

Pupuk urea dan ponska tersebut oleh Lembaga Keuangan Desa dijual dengan harga kredit dan dapat dibayar setelah panen. pupuk urea dijual dengan harga Rp. 72.000 , - per sak dengan berat per sak 50 $\mathrm{Kg}$, dan ponska dijual dengan harga $\mathrm{Rp}$. 42.000,- per sak dengan isi $20 \mathrm{Kg}$. jika dibeli oleh petani, Lembaga Keuangan Desa hanya membebankan biaya administrasi masing-masing sebesar Rp. 12.000,- kepada petani. Jadi jika petani membeli satu sak pupuk urea kepada Lembaga Keuangan Desa harganya menjadi Rp. 84.000,- dan harga pupuk ponska menjadi Rp. 54.000,-. Jika dijumlahkan harga pupuk urea dan ponska hanya sebesar Rp. 138.000,- itupun pembayarannya dapat dicicil setelah panen.

Jika dibandingkan dengan pedagang pupuk yang lainnya, biasa mereka menjual pupuk dengan cara kredit kepada petani tetapi dengan memakai sistem barter. Maksud kata kredit disini yaitu pembayaran pupuk dapat dilakukan setelah panen, sedangkan sistem barter yaitu pupuk yang tadinya di ambil sebelum 
panen harus dibayar dengan hasil panen bukan uang tunai.

Seperti yang diungkapkan oleh Bapak Anton Amu (wawancara, tanggal 1 Juli 2014) beliau mengatakan mekanisme yang diterapkan oleh pedagang pupuk sangat merugikan petani, karena jika petani membeli pupuk kepada pedagang pupuk, harga pupuk urea $50 \mathrm{Kg} \mathrm{Rp.} \mathrm{72.000,-}$ harus ditukar dengan cabe $5 \mathrm{~kg}$ sampai 10 Kg pada saat panen. Jika harga cabe pada saat panen Rp. 30,000/ 1 Kg maka harga pupuk yang harus dibayar petani setelah panen adalah Rp. 150,000-Rp. 300,000 Petani tentunya mengalami kerugian karena harga pupuk tidak sebanding dengan harga cabe untuk membayar pupuk tersebut selisihnya adalah Rp. 78,000-Rp. 280,000. Angka ini tentunya sangat berarti bagi petani kecil seperti mereka.

Harga pupuk pada Lembaga Keuangan Desa sangat berbeda dengan harga pupuk yang ada pada pengecer pupuk ungkap bapak Husain Yunus (wawancara, tanggal 1 juli 2014). Seperti telah dijelaskan di atas bahwa Lembaga Keuangan Desa memberikan transparansi harga kepada petani, berapa harga pokok pupuk urea dan ponska pada produsen, dari harga tersebut Lembaga Keuangan Desa hanya menambahkan Rp 12.000,untuk Pembayaran pupuk tersebut. Keuntungan yang didapat dari hasil panen petani pun bisa lebih maksimal.

Islam mengenal adannya nilai-nilai spritual pada setiap materi yang dimiliki, yang menjadi sentral dari konsep moralnya adalah semua barang milik Allah SWT dan bagaimana melakukan transaksi perdagangan yang sesuai dengan aturan syariat Islam. Sebagaimana firman Allah

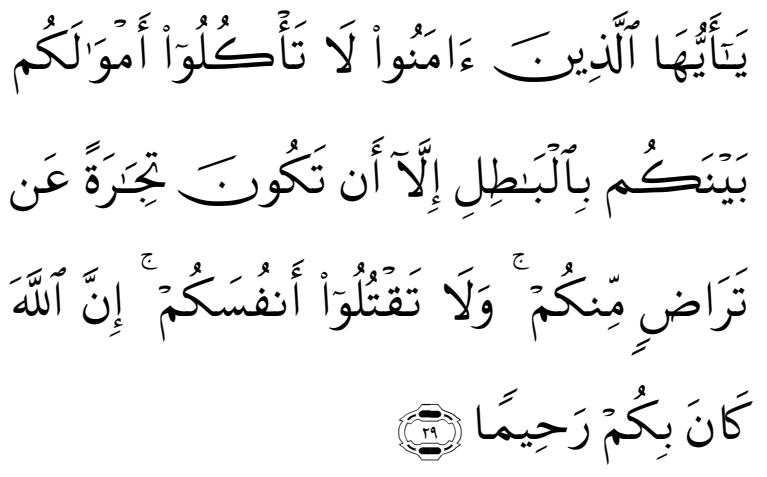

Terjemahannya:

Hai orang-orang yang beriman, janganlah kamu saling memakan harta sesamamu dengan jalan yang batil, kecuali dengan jalan perniagaan yang Berlaku dengan suka sama-suka di antara kamu. dan janganlah kamu membunuh dirimu Sesungguhnya Allah adalah Maha Penyayang kepadamu. (An-Nisa : 29)

Ayat di atas sangat jelas bahwa mekanisme suka sama suka adalah panduan dan garis Al Qur'an dalam melakukan kontrol terhadap perniagaan. Jadi dalam melakukan transaksi jual beli jangan sampai merugikan pihak lain. Perekonomian Islam harus berdiri di atas perekonomian tanpa bunga. Oleh sebab itu, transaksi yang dijalankan dalam kerja dan bisnis mengacu kepada konsep fiqh muamalah yang sudah dikonvergensi dengan sistem ekonomi dan keuangan modern. Substansi dari pelarangan riba adalah untuk mengantisipasi adanya tindakan eksploitasi terhadap mereka yang lebih lemah/kecil.

Bapak Piyon A.Launuha (wawancara, tanggal 2 juli 2014) mengatakan bahwa jual beli yang diterapkan Lembaga Keuangan Desa sudah sesuai dengan konsep Islam, karena dalam setiap proses kegiatannya tidak mengandung unsur Paksaan serta tidak memberatkan pihak petani dalam pembayarannya. 
Konsep jual beli yang diterapkan oleh Lembaga Keuangan Desa mencerminkan sistem jual beli dalam Islam. Sebagaiman kita ketahui bersama, jual beli dalam Islam mengajarkan bahwa dalam melakukan transaksi jual beli, salah satu syaratnya adalah barang tersebut harus jelas bentuk barang dan juga hargannya. Lembaga Keuangan Desa menjual pupuknya kepada petani dengan memberitahukan terlebih dahulu harga pokoknya kepada petani kemudian secara jelas memberitahukan kepada petani bahwa setiap pembelian pupuk akan dikenakan biaya administrasi, jika petani setuju maka terjadilah kesepakatan dalam pembelian pupuk.

\section{Peran di Bidang Sarana Alat Mesin Nelayan}

Sebagai salah satu badan usaha yang bergerak dibidang Kemasyarakatan, tentunya masyarakat nelayan pun tidak pernah luput dari perhatian manajemennya. Untuk masyarakat nelayan, Lembaga Keuangan Desa di Desa Olele menyediakan segala sarana yang sangat dianggap penting untuk mempermudah mereka dalam berusaha memenuhi kebutuhan keluarga mereka sehari-hari. Alat Mesin Nelayan ini oleh Lembaga Keuangan Desa kepada masyarakat berikan dua pilihan, pilihan pertama dipinjamkan kepada nelayan, dengan catatan hasil yang didapatkan 1/3 bagian untuk disetor pada Lembaga. Pilihan kedua, bisa saja masyarakat nelayan mengambil dengan sistim utang, dan menyetor kepada Lembaga Keuangan Desa jika mendapatkan hasil dari usaha itu tanpa ada ketentuan atau paksaan dalam hal jumlah setoran.

Namun oleh pihak Lembaga Keuangan Desa, diharapkan masyakat lebih memperhatikan Lembaga untuk merasa memiliki. Jika demikian maka Lembaga
Keuangan Desa tetap hidup dari masyarakan, oleh masyakat, dan untuk masyarakat.

Nelayan merasa terbantu dengan program pengadaan sarana alat mesin nelayan ini, karena dengan bantuan mesin mereka tidak susah lagi untuk mencari nafkah keluarga, serta waktu yang digunakan untuk pergi kerakit lebih sedikit. Dibandinkan dengan turun ke laut menggunakan alat yang sifatnya manual (dayung), sebab tenaga mesin jauh lebih cepat. Hal ini secara otomatis dapat mempercepat gerak perahu sehingga nelayan tidak merasa sangat terlambat dalam menjangkau tempat kerja utama mereka

Tujuan utama Lembaga Keuangan Desa menyediakan Alat Mesin Nelayan yaitu untuk memudahkan para nelayan dalam menjangkau jarak tempuh yang begitu jauh. Masalah pembayaran tentu bagi para nelayan tidak menjadi kendala. Sebabnya, jika tidak mendapat hasil dari usaha mereka pada saat itu, Lembaga Keuangan Desa tidak ada paksaan dalam meminta bagian pendapatan. Bapak Pardin Husa (Wawancara, tangga 2 juli 2014) mengatakan bahwa alasan masyarakat nelayan mengunakan Alat Mesin Nelayan yang ada pada Lembaga Keuangan Desa karena harganya yang murah serta pembayarannya pun bisa setelah mendapat hasil ataupun dicicil setiap hari atau minggu. Sehingga membantu masyarakat yang kurang mampu ketika musim ikan tuna.

Sistem sewa menyewa dalam Islam di kenal dengan ijarah. Menurut fiqih islam sewa menyewa adalah memberikan suatu benda kepada orang lain dengan tukaran atau imbalan sebagai bayaran atas penggunaan manfaat barang yang disewakan. Barang yang disewakan dapat berupa rumah, kenderaan, pakaian, sawah, 
ladang, tanah dan lain sebagainya. Namun yang perlu diingat, barang yang disewakan adalah barang yang tidak akan berkurang dzatnya. Jadi barang yang dapat berubah dan berkurang dzatnya tidak boleh disewakan, misalnya makanan, buahbuahan, dan lainnya (Hairunnisah, 2008). Ijarah menurut imam syafi'i (Al Jaziri, 1994: 172) adalah suatu perjanjian atas manfaat yang diketahui disengaja, yang bisa diserahkan kepada pihak lain secara mubah dengan ongkos yang diketahui. Jadi sewa menyewa merupakan akad pertanggungan antara pihak yang membutuhkan peralatan tersebut dengan orang yang menyewakan barang tersebut.

Dari pengertian ijarah di atas maka konsep sewa menyewa yang dilakukan oleh Lembaga Keunagan Desa dapat dikatakan telah sesuai dengan konsep ekonomi Islam, hal ini terbukti dalam sewa menyewa yang dilakukan Lembaga Keuangan Desa diketahui harga penyewaan barang, bahkan dengan peminjaman tidak terbatas waktu, selama barang itu masih dibutuhkan maka selama itu pula manfaatnya masih bisa dinikmati.

Dari uraian di atas maka program kemitraan lahan dalam hal pembiayaan, maupun sarana alat mesin nelayan yang jalankan oleh Lembaga Keuangan Desa telah meningkatkan kesejahteraan petani dan nelayan di desa Olele Kecamatam Kabila Bone Kabupaten Bone Bolango. Indikator untuk mengukur tingkat kesejahteran masyarakat meningkat meliputi:

a. Petani yang dulunya memiliki keterbatasan kemampuan untuk mengelola dan menggarap lahannya karena keterbatasan modal untuk mengelola lahan sendiri, setelah bekerja sama dengan lembaga keuangan desa (LKD), maka masyarakat petani barulah merasanya nyaman dan bisa menetap dalam bekerja dengan adanya modal yang diberikan oleh lembaga keuangan desa.

b. Pendapatan petani meningkat. Sebelum lahannya ditebus oleh Lembaga Keuangan Desa pendapatnnya sebagai buruh tani sebesar 500.000 permusim. Setelah lahan petani tersebut diambil alih oleh Lembaga Keuangan Desa pendapatannya meningkat menjadi Rp. 2.000,000 - permusim setelah dipotong dengan biaya produksi, 1/3 untuk Lembaga Keuangan Desa, dan 1/3 untuk bayar cicilan modal lahan pada Lembaga Keuangan Desa.

c. petani yang sebelumnya tidak memiliki tabungan keluarga, tidak pernah memperoleh berita dari surat kabar, radio, TV, dan majalah, dan tidak menggunakan sarana transportasi, setelah bekerja sama dengan Lembaga Keuangan Desa mereka sudah dapat menggunakan sarana trasportasi berupa motor walaupun memperolehnya dengan cara kredit, dapat memeroleh berita dari tv, dan sudah mempunyai tabungan keluarga.

d. Petani tidak berat dalam memproduksi hasil pertaniannya, karena sarana Produksi Pertanian dapat diperoleh dengan mudah dan harganya terjangkau .

e. Bagi nelayan, dengan adanya Lembaga Keungan Desa Di Desa Olele, pendapatan mereka pun meningkat disebabkan dalam hal menjangkau tempat ketika telah beroleh hasil, tidak was-was lagi jangan sampai ikan hasil tanggapan dagingnya akan rusak, sehingga setelah mendapat satu ekor tuna masih bisa lagi melanjutkan untuk mendapatkan yang lainnya, karena kekwatiran terlambat memasukkan ikan hasil tangkapan 
kepada para pengusaha penampung ikan tidak ada lagi, mereka telah dibantu dan dipercepat oleh mesin yang diberikan oleh Lembaga Keuangan itu sendiri.

Dalam pembahasan di atas, masalah program yang telah dilaksanakan oleh Lembaga Keuangan Desa (LKD) terlihat bahwa, segala kebutuhan masyarakat terpenuhi, ini membuktikan kebenaran program Lembaga Keuangan Desa dapat memberikan kesejahteraan yang maksimal kepada masyarakat Olele terutama bagi mereka yang sangat membutuhkan. Sebaliknya perasaan terbebani dengan adanya utang yang harus disetor setiap bulan kepada Lembaga Keuangan Desa oleh masyarakat bukanlah sesuatu yang menyengsarakan dalam penyetorannya, akan tetapi justru menjadi sebuah kewajiban yang harus dipenuhi sesuai perjanjian, karena telah membantu meningkatkan kesejahteraan mereka.

4. Sistem Lembaga Keuangan Desa Dalam Pengelolaan Keuangan

Lembaga Keuangan Desa (LKD) di

Desa Olele Kecamatan Kabila Bone Kabupaten Bone Bolango tentunya tidak lepas dari catatan dan pembukuan yang dibutuhkan. Dalam hal pengelolaan keuangan, Lembaga Keuangan Desa menggunakan beberapa buku yang menjadi bagian dari pencatatan dan pemberian Informasi penting kepada masyarakat pemanfaat keuangan yang berada di lembaga, sekaligus sebagai alat kontrol lembaga, agar nantinya kepada masyarakat, lembaga tidak akan salah memberikan informasi untuk penagihan atau pencatatan setoran dari masyarakat pemanfaat itu sendiri.

5. Kendala Lembaga Keuangan Desa dalam Meningkatkan Kesejahteraan
Petani dan Nelayan Di Desa Olele Kec. Kabila Bone Kab. Bone Bolango

Dalam menjalankan aktivitasnya Lembaga Keuangan Desa sudah pasti mengalami kendala dalam upayanya untuk meningkatkan kesejahteraan petani. Bapak Michtar Amu (wawancara tanggal 16 April 2014) mengatakan bahwa kendala yang dihadapi oleh Lembaga Keuangan Desa adalah kurangnya sumber daya manusia yang ada pada Lembaga Keuangan Desa itu sendiri, sehingga dalam menjalankan programnya Lembaga Keuangan Desa mengalami hambatan. Padahal sumber daya manusia merupakan salah satu faktor keberhasilan suatu daerah dalam mensejahterakan masyarakat.

Terhadap masalah yang dihadapi dalam upaya meningkatkan kesejahteraan petani, Bapak Tiyong Mahmud (Wawancara Tanggal 17 April 2014) mengemukakan bahwa salah satu kendala yang dihadapi oleh Lembaga Keuangan Desa adalah kurangnya modal yang dimiliki oleh Lembaga Keuangan Desa, bantuan yang diberikan pemerintah masih sangat sedikit untuk menanggulagi permintaan masyarakat yang banyak terkait dengan masalah pertanian. Akibatnya masih banyak petani yang menjadi buruh tani pada lahannya sendiri.

Permasalahan lainnya dikemukakan oleh Bapak Lutfi Rahman (wawancara tanggal 17 April 2014) bahwa saat ini upaya-upaya untuk meningkatkan kesejahteraan petani sudah digalakkan. Salah satu contoh adalah dengan munculnya program pemberian modal lahan bagi masyarakat petani, kendala yang dihadapi oleh Lembaga Keuangan Desa adalah para pemegang lahan (tengkulak) tidak mengizinkan lahan petani ditangani oleh Lembaga Keuangan Di Desa. Hal ini dikarenakan mereka ingin meraup keuntungan lebih besar lagi dengan 
mengelola lahan petani tersebut, dan untuk menghindari konflik dengan pemegang lahan sebelumnya (tengkulak), Lembaga Keuangan Desa memberikan dananya kepada petani, agar mereka sendiri yang akan membayar utang lahannya kepada tengkulak tersebut.

Demikian untuk nelayan, masih banyak masyarakat yang keinginannya bisa ditanggapi dengan baik oleh Lembaga Keuangan Desa (LKD), sebab modal yang ada juga belum mencukupi untuk melayani keseluruhan. Berdasarkan uraian - uraian tersebut diatas maka pada dasarnya kendala utama yang dihadapi Lembaga Keuangan Desa dalam upaya meningkatkan kesejahteraan petani dapat diklasifikasikan sebagai berikut :

a. Terbatasnya modal usaha

b. Terbatasnya kemampuan pengelola baik dalam hal kuantitas maupun kualitas sumber daya manusia.

c. Gagalnya panen dimusim panen membuat petani tidak mampu mengembalikan cicilan kepada Lembaga Keuangan Desa ( kredit macet)

d. Kurangnya persediaan Alat Mesin Nelayan yang dimiliki oleh Lembaga Keuangan Desa sehingga banyak nelayan yang masih menggunakan Alat Mesin Nelayan yang disewakan dengan harga mahal, bahkan sebagian masyarakat masih menggunakan alat manual.

\section{E. Kesimpulan}

Peranan Lembaga Keuangan Desa (LKD) di Desa Olele Kecamatan Kabila Bone dalam upaya meningkatkan kesejahteraan para nelayan, pedangan kecil, dan yang paling utama adalah petani, mendapatkan respon yang sangat baik dari masyarakat. Hal ini dapat dilihat dari banyaknya masyarakat yang ingin bergabung dan bekerjasama dengan Lembaga Keuangan Desa (LKD) yang bergerak dibidang perikanan, serta pertanian, program-programnya dituntut untuk selalu menyentuh masyarakat khususnya petani, sehingga membuat masyarakat merasa diperhatikan oleh pemerintah. Lembaga Keuangan Desa (LKD) melalui Program kemitraan lahan, pemberian modal, sarana produksi pertanian, dan pelayanan alat mesin nelayan, semenjak tahun 2009 sudah mampu meningkatkan kesejahteraan masyarakat walaupun belum disemua lapisan masyarakat Desa Olele. Utamanya Kesejahteraan petani dapat diukur melalui beberapa indikator antara lain kembalinya lahan pertanian yang dikuasai oleh para tengkulak sebagai objek pencarian nafkah, kebutuhan primer seperti makanan, pakaian, perumahan, pendidikan dan perawatan kesehatan yang sebelum adanya LKD terkadang sulit terpenuhi,sekarang sudah dapat terpenuhi dengan hadirnya LKD di desa Olele, naiknya pendapatan membuat taraf hidup mereka meningkat. Maka dengan pernyataan-pernyataan tersebut, LKD memiliki peranan yang sangat besar terhadap peningkatan kesejahteraan masyarakat di Desa Olele Kec. Kabila Bone Kab. Bone Bolannn.

Kendala yang dihada 'mbaga Keuangan Desa dalam upaya m. „katkan kesejahteraan petani, nelayan adalah 1).Terbatasnya modal usaha yang dimiliki oleh Lembaga Keuangan Desa. 2).Terbatasnya kemampuan pengelola baik dalam hal kuantitas maupun kualitas sumber daya manusia. 3).Banyaknya pesaing Lembaga Keuangan Desa seperti pengusahan yang berbeda tujuan dengan LKD. 4).Gagalnya panen dimusim panen membuat petani tidak mampu mengembalikan cicilan kepada Lembaga Keuangan Desa. 5).Kurangnya persediaan 
alat mesin Nelayan yang dimiliki oleh Lembaga Keuangan Desa sehingga banyak nelayan yang masih menggunakan alat nelayan yang sifatnya manual atau yang disewakan dengan harga mahal oleh pihak lain (tengkulak).

Dalam upayanya untuk lebih memaksimalkan kinerja dalam rangka meningkatkan kesejahteraan masyarakat, Lembaga Keuangan Desa dapat melakukan penyuluhan - penyuluhan dibidang pertanian baik berupa penyuluhan cara penanaman benih yang benar, cara memilih bibit unggul, pemeliharaan tanaman yang baik, dan cara untuk memasarkan hasil pertanian dengan benar kepada petani, sehingga ilmu pengetahuan petani bertambah. Dengan ilmu pengetahuan yang lebih, otomatis petani tersebut mampu bersaing dengan pengusaha-pengusaha yang bergerak dibidang pertanian lainnya. Lembaga Keuangan Desa juga dapat membuka program yang melakukan pembibitan benih jagung dan cabe agar masyarakat yang berada di Desa Olele dan sekitarnya tidak akan kesusahan mencari bibit unggul yang berkwalitas tinggi dengan harga dapat dijangkau oleh masyarakat khususnya petani kecil.

Menambah modal usaha untuk pengembangan Lembaga Keuangan Desa (LKD) kedepan. Dengan bertambahnya modal maka biaya operasional lainya akan terpenuhi. Untuk lebih meningkatkan sumber daya manusia yang ada pada Lembaga Keuangan Desa dengan menempatkan karyawan yang ahli dibidangnya dan mengetahui batas kemampuan dirinya sehingga manajemennya akan berjalan dengan baik. Manajemen perusahaan yang baik akan membawa perusahaan maju dan berkembang sehingga misi utama perusahaan tercapai dengan maksimal. Perbaikan sarana dan prasana yang ada, juga merupakan faktor yang penting untuk menunjang kinerja karyawan. Dengan sarana dan prasarana yang memadai akan membuat karyawan bersemangat dalam mengerjakan tugas-tugasnya.

\section{DAFTAR KEPUSTAKAAN}

Abdulrahman Al Jaziri, 1994 Al Fiqh 'Alal Madzabihil arba'ah, Figh Empat Mazhab, di terjemahkan oleh Drs Moh. Zuhri, Dial, Talf (et..Al.), (Semarang ; Asy Syifa).

Ahmad. Ziauddin. 1998. Al Quran, Kemiskinan dan Pemerataan Pendapatan, Jakarta: Dana Bhakti Prima Yasa

Al Ghazali. Abu Hamid 1997, Ihya 'Ulum Al Din, Beirut : Dar al- Nadwah,t.t

Departemen Agama RI, 2001. Al Qur'an dan Terjemahannya Dengan Transliterasi Model Per Baris,Semarang: CV. Asy Syifa'

Hairunnisah, 2008 Bina Fiqih Madrasah, (Erlangga).

Hasan Ali, 2004. Berbagai

http://ayutyap.blogspot.com/2011/11/definis i-lembaga-keuangan-dan lembaga.html

http://zanikhan.multifly.com/journal/item/ 698, tanggal 16 Oktober 2013

Karim Adiwarman Azwar. 2000. Sejarah Pemikiran Ekonomi Islam, Jakarta; Rajawali Pres Edisi ke3 
M. Quraish Shihab. 2000. Tafsir Al Mishbah, Pesan, Kesan, dan Keserasian Al Quran, Lantera Hati

Nur Rosihin Ana, www. Naghata.blogspot.com

Qaradhawi Yusuf, 2002. Musykilat al Faqr wa Kaifa' Alajaha al Islam, Teologi Kemiskinan, penerjemah, A. Maimun Syamsuddin, Yogyakarta; Mitra Pustaka

Sadikin. Ikin dan Subagyono. Kasdi. 2008. Kinerja Beberapa Indikator Kesejahteraan Petani Padi Di Pedesaan Kabupaten Kerawang, Jawa Barat : Badan Penelitian dan Pengembangan Pertanian
Suharto Edi. 2009. Membangun Masyarakat Memberdayakan Rakyat, Jakarta: PT Refika Aditama

Said Husain. 2004. Membangun Ekonomi Yang Berkeadilan. Yogyakarta. Insania Press

Soeratno, 1988, Metodologi Penelitian, Yogyakarta: UPP AMP YKPN, cet. I

Suprayogo. Imam dan Tobroni, 2003. Metodologi Penelitian Sosial-Keagamaan, Bandung: Remasa Rosdakarya, cet II www.bkkbn.go.id tanggal 24 Oktober 2013 